\title{
Factors that Hasten the Integrity of Albania in the European Union
}

\author{
Arjan Gjini \\ PhD, Candidate, \\ Albanian University of Tirana
}

Doi: 10.2478/ajis-2018-0034

\section{Abstract}

European Union is nowadays the most popular term used in Albania. Its integration means development, solidarity, justice, equality. Data of verified polls reveal Albania as the most enthusiastic country, bearing the highest percentage of popularity willing to join EU. Ben Rosamond defines European Union as an "endless, deep, broad process of the politic, economic and security cooperation among nations with the intention to restore peace"1. North Europe has been called Europe by greeks in the VII century B.C, naming it after the name of the Phoenician king's daughter who was brought in Crete by her absconder Zeus. The integrity process is complex, complicated, multidimensional and deep in reforms of all fields. It is a long process with great responsibility that requires a big invest in fulfilling standards. The psychological factors have their role and impact in all other factors hasting this process.

Keywords: Albania, Integrity, European Union(EU), prosperity, development, poll.

\section{Growth of Faith, Awareness and Real Efforts of the Albanians to become a Part of the EU}

In the report of EU to Albania it is stated "Growth of awareness about real efforts and time that Albania needs to integrate in EU is crucial. Contrary, the chances of disappointmnet would be high." 2

1.1 It is important to grow faith that the day of Albania acceptance in EU will not be too far and to create a positive enthusiastic atmosphere.

Recognition of achieved results, initiating a competitive spirit, praising and rewarding all those who work for and help in european integrity - are important psychological elements of growing faith and enthusiasm. In our way to integrity, we as Albanians need to be incouraged and stimulated in order to move ahead courageously and boldly.

According to the psychologists "Courage is not an isolated aspect, a momental impuls. It is a complete and complex action that should be followed till the final goal. It is not the initial efforts that are the most difficult, but rather those halfway trying to resist the weaknesses and unpredicted barriers. It is important to face these difficulties with patience and caution. Courage is not the virtue of starting a work but, rather its further continuance, completion and perspective."3

The creation of a positive, enthusiastic atmosphere is achieved when national consensus on major issues is achieved, such as the case of integration in EU. Our country needs a wise

\footnotetext{
${ }^{1}$ Rosamond, B. (2000) Theories of European Integration. Basingstoke: Macmillan

${ }^{2}$ Meksi, E. Challenges and perceptions, Publishing House Dudaj, Tirane, 2005, p.225

${ }^{3}$ Alberon, F. To have courage, Dritëroi, Tiranë, 2001, p.41
} 
pragmatic politics in order to achieve this consensus. It is required the increase in level of Albanian politics wisdom to answer to European standards with the same norm. All Albanians are required to be aware of the reform cost and move together towards Europe without political discrimination.

With our eyes and efforts on the future, visions are possible and realisable, whether immediately or gradually, when they are relied on tangible reality combined with a clear political will. If we are to consider the survey results through years, we reach to the conclusion that the number of the Albanians defending the idea that integration does not depend on Brussels but on internal reforms, is rising ${ }^{4}$. The internal call, belief, reliance on internal factors, as the most fundamental, create the possibility to get in touch with profound dynamisms that support and lead us, relieve from the fear, exhaustion so as to get as soon as possible where we aim at.

\subsection{Citizens awareness of the integration necessity of our country in EU.}

Individual awareness is an important factor of its motivation. European integrity is a motivated process of the Albanians to be member of the european family. This is connected to the affirmation wish of the Albanians as equal to Europe nations, to strong wish of solving economic issues, the same as Europe did, to the desire to adjust to technology, to lifestyle etc.

Our motivation, already focused on EU integration, requires:

Firstly, when dealing with people, the concetration must be on good behaviours, education of humanism, tolerance, solidarity and respect of law execution. Integration and moral values cultivaton, rules and laws are very important. These are related to membership itself in EU, open to every European state that respects "liberty, democracy and respect principle of human rights, fundamental freedom and legal state".

Secondly, all the citizens, but also the political class should be aware of their responsibilities in hastening or slowering the integration process by giving what they can. Psychological awareness or preparation must be an inseparable part. A song by some USA pupils mentions : "What an illuminated world would we have if each one of us lighted a single small candle".

We should join EU with dignity, with our etnopsychological features and with our identity. The motif of affirmation, success achievement, interest, curiosity, perfection and prestige stimulate the individual to reach self perfection and help others move towards the European integrity.

The typical Albanian is proud, sensitive, sensible and these qualities must be a reason to move faster towards integration. The support this process has from individuals is a positive aspect in the favorable politics compilation. As Prof. Dr.Ermelinda Meksi, Minister of European Integration in 2002-2005, stated "a fundamental factor speeding the European integration are we ourselves, through our vision perspective, leadership and awareness to our political compromises". 5

The role of interest is great, especially from the part of the youth when it is strong, profound and long-term. Interest on activities that give success, also give a special satisfaction. Albanians want success and fight for it. This aspect should also be seen as positive integration stimulator.

\subsection{Abilities, expressions, skills as part of faster integration in EU.}

Skills are individual features of human personality that help them succeed in a certain field or activity. As far as kinds of skills are concerned, lets mention intelectual, mental ones, the latter being the most important. An integrated school of the European educational system accomplishes the mission of integrity. Expressions are a set of learned movements based on systematic exercises applied automatically, whereas skills are the fast, correct executions of certain professional, sportive actions. They are human flexibility in work, play and other activities. Both of them economize the individual activity by providing premises and time to intelectual and productive actions. They are taught early in age. We see it necessary to taught our pupils, make them be aware of the time wasted and how to regain it. This might be done by changing our programmes and contexts.

\footnotetext{
${ }^{4}$ Survey on Albanians integration in EU, Albania Paper, 14.12.2004, p.11

${ }^{5}$ Meksi,E. Challenges and perceptions, Publishing House Dudaj, Tirane, 2005, p. 230 


\section{New Communication Strategies of Integration in EU}

Strategy, methods issues and communication techniques with public and European negociators are the key to success of integration hastening. We as people of a country that aims at joining with the great European family, already part of the integration process, need to know EU better, its history, essence, gradual integration and universal politics, benefits and liabilities of being its member, acceptance conditions, mechanism of mutual institutions function etc.

\subsection{Communication is always a thought, sense and behavior.}

"The flow of events must change but, first must change the spirit of people."

The psychology of communication teaches us that in order to be communicative, guidelines in form of recipes are not sufficient. (Let alone when communication happens with ancient, civilized and prosperous Europe).

What must be learned about sending and receiving a message is understanding what happens when we communicate, as well as being able to adjust to communication circumstances. Our messages to Europe must be clear, friendly and applying widely.

Messages must also be understood and desciphered in time with intelligence. It is really important to teach communicative behaviour in order to develop abilities, skills and communication expressions that have civilised features. This must be part of the work in our schools. To establish a relationship it is important to reach people's sense. The word power is the only real moving force in the invisible thought kingdom. According to the philosopher Umberto Eco "The integration culture is within the human being itself, it is the culture of planetary identification, survival but, always a culture with lively and multiple plurality." 8 Starting from this, very important, with positive impact that leave imprints are the meetings in form of discussions and focus on:

1. Improvement of public knowledges and understanding of EU.

2. Explanation of the complications that will be present when each country is accepted as a member.

3. Explanation of the relations between efforts of membership preparations and negotiations progress.

Debates and discussions are present even in the position of the European citizen during his process of integration in countries of West Balkan. We should take the initiative to communicate with EU. This requires a serious preparation, wise attitude, excellent knowledge of EU countries, their psychology, a qualitative communication and finding the right moment to communicate. When communicating with EU, it is with great importance the role of observation strategy, interference, when necessary, the strategy of real approach to Europe, collaboration strategy, partnership, persuasion, incentive and situation dominance, persistence in main motif and national interest defense. ${ }^{9}$

Albanians should be informed about integration politics of Albania in EU, the process and qualities of EU institutions functioning with the intention to develop their programmes on a wellinforment bases. The school has an important role in its contemporary European curriculum.

Educational subjects that teach about EU institutions are: European Parliament, Counsil of Ministers, European Counsil, Court of Justice, Court of Accounts, Economic and Social Counsil, Regional Committee, European Bank of Investments. In the subject of "Economics" : What is the concept of EU on social politics (politics related to relationships in work and not in health, accomodation or social services which the Office of Social Aid deals with). Where do these politics focus on: work conditions, the improvement of work place so as to protect the health and safety of

\footnotetext{
${ }_{7}^{6}$ A group of authors, European Union, Publishing House AlbPaper, Tirane, 2002, p.5.

${ }^{7}$ A group of authors, European Union, Publishing House AlbPaper, Tirane, 2002, p.11

${ }^{8}$ Meksi, E. Challenges and perceptions, Publishing House Dudaj, Tirane, 2005, p.15

${ }^{9}$ Çomo, Bekim, Communication Psychology, Pegi, Tirane, 2001, p.34
} 
the employers, informing and consulting with them, equality of men to women, integrity of individuals expelled from the work trade. ${ }^{10}$

In the subject "Knowledge on society": it is intented to get extra informaton about "How is EU represented in the Common External and Security Politics":

- EU Presidency

- Commissioner of External Relationships

- High Representative in Common External and Security Politics (General Secretaire of the Counsil)

- External Common Services of the Commission on Exteral Relationships

- Development

- Expansion

- The Office of Humanitarian Aids - ECHO

- Counsil Secretariat

- Politics Planification and the Unit of Preliminary Signalisation.

Means of communication are various and interesting: quick information through internet, broadcast of TV spots, important release on media, documentaries and films on the work about European integration, videoclips, different exhibitions with the intention real image promotion of Albania, 3-6 months and annual bulletins, special publications of Integration Ministry, External Ministry, Justice Ministry, Internal Ministry, Economy Ministry, Finance Ministry, Wellbeing Ministry. Through these means and publications the Albanians know what standards should be achieved:

a) in economy - an active trade economy, price liberalization, trade liberalization, macroeconomic stability, rights on property, privatization, financial sector development, competition politics.

b) in way of governance - votes and responsibility, politic stability, government efficiency, regulative quality, law domination, control of corruption, vulnerability to reality (how vulnerable are we to reforms progress).

It is important to use communication techniques that provide a reciprocal confidence situation, both for Albanians and Europeans. These techniques have positive impact if there are applied ways of reducing the difficulty in dialogues and if there are selected proper attitudes that give results.

c)in administrative field - the ability to take on the membership liabilities, including the loyalty to political, economical and monetary unions.

European integrity and public politics are tightly connected to each other. The public politics lie on citizens acting themselves to gain a greater control on their income. It is the Albanians right to know more about the politics, economy, culture, traditions and history of Europe. They require a beat of public views about integration issue. This does not mean only discussion or understanding. Effective beat of thoughts cannot go without decisions related to public acts. Democracy is the vision of a willing cooperation which many important initiatives are based on.

These must be oriented and directed towards European integration of our school. Integration is realized by people with common views and based on the power of reciprocal vows. The new communication strategy should focus on participation increase and active role of the public even on important decisions.

\subsection{Creative and qualified work in the European integration of our country.}

Methods and ways to realize this work are various. We have the chances to make attractive and useful things. Two points are on our advantage: intelectual capacities and the experience of East Europe countries (almost all these countries overcame the great challenge of European integration)

What can be offered to Albanians in the future:

- A better qualified job so as to transmit the important message to the new generation.

- Hastening or slowering of integration is up to us, Albanians, political forces in our place,

\footnotetext{
${ }^{10}$ Pinder, Jon, European Union (Brief introduction), Publishing House Ombra GVG, Tirane, 2001, p.110
} 
their consensus, reforms execution in all spheres etc.

- Albanians must know that "the European miracle" came with work, expenses, because it has its own financial cost and requires standard achievements. ${ }^{11}$

Before giving dates on EU acceptance, lets work together and give the best so as the process flows naturally. It is required:

- To be established information centers of EU all over the country. In web pages near them new information related to developments and changes in EU gets in. In Latvia, before its membership in EU, there used to be 32 information topics in different regions.

- To supply libraries with books about EU. It is required also to be organized "The Day of European Poetry" and "The Day of European Prose".

The European literature will help in knowing the life of European popularity, their psychology, traditions and manners, language and history. In history subject, especially in economic geography, new information is added. Contexts must be refreshed and new small books (appendixes) be published. Political changes and economic developments are really fast. EU consists of 27 states, new ones will soon be members and others aspire.

- Citizens should get constant information on EU negotiations in forms of leaflets, be stimulated to negotiate well and contribute on their country.

- A national information center should be established, where a specialist of European issues is available to take notes, deals with concernes which he replies directly or electronically to.

- To be planned "The Days of Europe", "The Weeks of Europe", festival of European film and music with participation of many citizens. The motto of Europe be: "DemocracyDialogue-Debate". Among the most important personalities in politics, art, culture and science, especially those who studied and worked in countries of EU are invited to give some clues on their experience and efforts to enter the EU. What are they doing right now, how do they feel and what is the future of their country?

- Competition between EU countries in different areas: history, geography, literature, art, music, sport. National competition "How to be a good negotiator" according to Polish experience. The winners will be awarded with a visit to one of the EU countries.

- Brochure in form of EU dictionary and ABC of community law. A special school book "European Integrity" be added as soon as possible to school curriculum.

- Polls on European integration issues. Results must be published and analyzed by qualified people who have good knowledge on EU countries, concerns and disagreements on specific topics.

\section{Conclusions}

The European integrity of our country is an objective, irreversible projects - the biggest one of the Albanians since the fall of totalitarian system. Albanians see they have a future in EU. "Europe" does not mean a geographical aspect but, rather a spiritual one. ${ }^{12}$

A century ago our Renaissance activists expressed the wish to be part of Europe. The lines: "Jak, blessed day that starts where it goes down" - are meaningful, actual and express the spiritual bond of Albanians with West. In surveys conducted years ago, $89 \%$ of the Albanians were pro integration to $\mathrm{EU} .^{13}$

Motifs are some: economic advantages, political stability, democracy and legal state consolidation, free movement of Albanians. Robert Schuman states : "Europe is not going to be formed immediately. It requires concrete achievements." ${ }^{14}$

\footnotetext{
${ }^{11}$ The action plan of priorities execution of the European partnership document. Publication of Integration Ministry of Albania, 2004, Tirane

${ }^{12}$ A group of authors, European Union, Publishing House AlbPaper, Tirane, 2002, p. 89

${ }^{13}$ Poll on Albanians integration in EU. Albania Paper, 14.12.2004. p.10

${ }^{14}$ Milo, Paskal, European Union, Publishing House AlbPaper, 2012, p. 53
} 
It is our turn now, through reforms and work, be part of EU as soon as possible. We need Europe and Europe needs us too. EU is the common home of European citizens. By becoming part of European Union we defend better our fundamental rights, provide safety, set justice, develop economy and strengthen the legal state. EU teaches us to find consensus on reforms and major decisions. Cooperation and responsibility of all political parties and citizens are the key words to the difficult and long way towards EU. Europe has given its critic and constructive view. ${ }^{15}$ Above all, starting from the example and Europe values, we should be more human because humanism is the original and typical creation of European culture. United Europe projecters emphasized that Europe became a geographical notion after being historical. Albanians, like Betty Dovis character in his movie "Everything about myself", will have to fasten belts because the travel will be difficult. ${ }^{16}$ The spring of Europe is always ahead.

\section{References}

Poll on Albanians integration in EU, Albania Paper, 14.12.2004, p.10

Milo, Paskal, European Union, Publishing House AlbPaper 2012, p.53

Morin, Edgar, Europe in our thoughts, Ora, Tirane, 2001, p.81.

Bogdani, Mirela, John, Loughlin, Albania and EU, Dajt, Tirane, 2004, p.108

A group of authors, European Union, Publishing House AlbPaper, Tirane, 2002, p.89.

In polls conducted years ago, $89 \%$ of the Albanians were pro EU integration.

The action plan of priorities accomplishment of the European partnership document. Publication of Integration Ministry of Albania, 2004, Tirane.

Pinder, Jon, European Union (brief introduction), Publishing House Ombra GVG, Tirane, 2001, p.110

New South Wales Treasury (2009) - New South Wales Public-Private Partnerships - An Evolution.

Deloitte Research (2006) - Closing the Infrastructure Gap: The Role of Public-Private Partnerships

European Committee (2003) - Guidelines for successful public - private partnerships

OECD (2009) - Bridging State capacity Gaps in Situations of Fragility

Agroup of authors, European Union, Publishing House AlbPaper, Tirane, 2002, p.11.

Meksi, E. Challenges and perceptions, Publishing House Dudaj, Tirane, 2005, p.15

Çomo, Bekim, Communication psychology, Pegi, Tirane, 2001, p.34.

Rosamond, B. (2000) Theories of European Integration. Basingstoke: Macmillan.

Meksi, E. Challenges and perceptions, Publishing House Dudaj, Tirane, 2005, p.225.

Alberon, F. To have courage, Dritëroi, Tirane, 2001, p.41.

\section{Websites}

www. europa.eu.int www. worldbank.org www.km.gov.al

${ }^{15}$ Morin, Edgar, Europe in our thoughts, Ora, Tirane, 2001, p.81

${ }^{16}$ Bogdani, Mirela, John, Loughlin, Albania and EU, Dajt, Tirane, 2004, p.108 